\title{
Revival? Rebirth? Renaissance?
}

What has happened to Polish Jews over the last four decades?

\author{
Konstanty Gebert
}

DOI: $10.30752 /$ nj.85207

AвSTRACT $•$ Drawing on personal experience, the author discusses the vicissitudes of Jewish identity formation in the last two decades of Communist Poland and the first two decades which followed. He addresses the role of religion in the Jewish revival which occurred in that period, and sets it against other models of Jewish identity - Zionist, Yiddishist and assimilationist - on the one hand, and the twin pressures of anti- and philosemitism in Polish society at large. This discussion is placed within the broader framework of the Polish political transformation. He finally suggests that the survival and revival of the Jewish community in Poland offers a more general lesson for the continuation of Jewish peoplehood.

Revolutions Do NOT GeT TO CHOOSE THEIR symвоLs. The French Revolution is for ever associated with the taking of the Bastille even though on that day the prison was almost empty, and its fall did not significantly impact historical developments, except for giving the French Republic its National Day. When we think of the Russian October Revolution we think of the storming of the Winter Palace. But that was militarily unimportant, politically insignificant and, if not for the masterful re-enactment in Sergey Eisenstein's October, it would have probably become just a footnote to history.

The same is true of 'The Fall of the Wall'. It sounds great, and rolls off the tongue with a rhythm of its own. And it is unbeatable in terms of sheer drama: the people, long oppressed, tearing down the wall of oppression with their own hands, or almost. But in this year of its thirtieth anniversary, it seems fair to remind us all that the Wall was toppled five months after Poland had its first, still semi-free elections, and two months after it had set up its first non-Communist government. To be sure, there is a reason why in Swedish a polsk riksdag, or Polish parliament, is a synonym of what in Hebrew is called balagan (בלבקן, a total mess, ultimately from Persian through Russian, Yiddish and Polish) - but that is simply what freedom looks like. Freedom is messy, and nobody in that parliament, or in the government it formed, had any experience in running a state. And yet they managed to yank Poland out of the socialist block, and with it gone, the entire construction started to crumble. It was thanks to that balagan that the Fall of the Wall was possible.

And in that balagan, a number of actors were Jewish: the names of Marek Edelman and Bronisław Geremek of blessed memory and that of Adam Michnik come to mind. 
Strange and wonderful news started coming from Poland: they have elections! They have overthrown censorship! They are moving towards free enterprise! And among that news even stranger reports came: they even have Jews there! Even Jews doing Jewish things! Good Jewish news from Poland - that sounded like an oxymoron. After all, Jewish news from Poland throughout the twentieth century had been almost consistently different kinds of bad. Yet reporters continued to insist that there was a Jewish rebirth, or revitalisation, or renaissance. Clearly, something re-Jewish was going on there.

And yes, a re-Jewish something was in fact going on. That 'something' still shapes the Jewish community in Poland, itself unimportant, as we are a very small community. But it also speaks to the very fundamental issue of Jewish continuity, of who we are - or, at least, who we think we are.

By the I970s, the consensus was that Judaism in Poland was over. The antisemitic officially 'anti-Zionist' - campaign of March I968 had forced the emigration of some I5, 000 people and that really seemed to be the last chapter. Yet, as an old Warsaw joke has it, each time the last Jew of Poland leaves Poland, a few hundred of his closest family and friends come to the station or airport to see him off. The March chapter turned out not to have been the final one. In the mid-I970s, a younger generation of Poles of Jewish origin started trying to figure out where they came from and what, if anything, these origins meant to them. These Poles of Jewish origin - from assimilated families, mixed marriages, with no Jewish knowledge or tradition from home - encountered Jewishness not as an abstract issue, but as a personal threat, for the first time in I968, and remained scarred by the experience.

In analysing subsequent developments, however, I believe it is important to keep separate three different processes which occurred at that time: the rebirth of a general interest in things Jewish, the re-emergence of antisemitism, and the renaissance of Jewish identities among assimilated Jews.

The general rebirth of interest in things Jewish within Polish society at large started more or less at that time, and continues unabated to the present day. Initially it was dismissed as a fad-but fads do not go on for more than forty years. It is sometimes mawkish and sentimental, or outright commercialised, as in the former Jewish district of Kazimierz in Cracow, but there is much more to it. It started largely as a moral movement, in reaction to official falsehoods which maintained, somewhat contradictorily, that there are no Jews in Poland and, even if there were some, they were unimportant, but Polish-Jewish relations were nonetheless wonderful. It was not difficult for young non-Jewish Poles to discover that these were lies - and in reaction they started digging, as young people will when they find out they have been duped.

There was an added bonus to it. You could say 'fuck' at your parents' dinner table, and at best someone would respond: 'Mind your manners!' - but if you said 'Jew', the conversation would drop dead. Everybody was uneasy with this subject. The Communists were, because they had the double handicap of both having had a number of Jewish activists in some very prominent positions and, more recently, having staged an antisemitic campaign. But anti-Communists were uneasy as well. Until I968 being anti-Communist was, in a way, simple: if you were antisemitic you were antiCommunist, because you believed in the myth of 'Jew Communism', that it was the Jews who had brought Communism to Poland. But also if you were anti-Communist you often were also antisemitic, for the very same reason. But once the Communists become antisemitic, as in I968, then you have a problem. You have to choose, because if you continue being 
antisemitic as before, you discover you are no longer as anti-Communist as you thought you were, since you share your antisemitism with them. And if you continue being anti-Communist, then your antisemitism starts getting uncomfortable, for the very same reason.

An old antisemite once complained to me: 'The Reds can ruin everything. A good thing like antisemitism, they took it and they ruined it.' And the veteran dissident, oppositionist and Solidarity leader Jacek Kuroń, who passed away in 2004, and is still missed, presciently said that, were it not for 1968 , Solidarity might have well ended up antisemitic, because of its anti-Communism.

But it was not only pro- and anti-Communists that were uneasy around the topic: so were the Catholics (who could be members of both groups, though mainly the latter). On the one hand their religion was founded by Jews, but on the other it had a long history of antisemitism, and on the third hand, it had broken with that tradition under the Second Vatican Council, which, a dozen or so years later was still a fresh and raw topic in Poland; then, on the fourth hand, Cardinal Karol Wojtyła had just become Pope John Paul II, and would revolutionise Catholic-Jewish relations ... You would need to be an octopus to sort all that out.

Everybody, therefore, had some skeletons in the closet, and everybody had a good reason not to revisit these closets. Young people sensed that, and took to making their elders uncomfortable - with a passion. Imagine being seventeen and having that power.

Young Catholics, though no octopuses, used Vatican II to bring back the Jewish issue. The Polish church, however, was in no hurry to endorse the new teachings: when you are a besieged fortress, the last thing you want to do is critically re-examine the foundations. But they persevered, and this led to the discovery of this huge black hole at the heart of contemporary Polish history, and to the realisation that you cannot really understand Poland without factoring in the Jews. This led to a flourishing of Jewish and Jewish-themed publications: I read my first Martin Buber in the Catholic liberal weekly Tygodnik Powszechny.

In the independent publications printed underground, which took off in the second half of the I970s, even more daring texts were produced: about I968, or about the impact of Jews on Polish history and culture. These publications helped educate Poles of Jewish origin - but targeted Poles of all denominations, not specifically Jews. This remains to this very day a major driving force for the Polish interest in things Jewish. It is a very important phenomenon - but it is not Jewish. It sometimes transforms into philosemitism, a love of Jews and things Jewish just for being Jewish. This is Poland sorting itself out, and though we Jews are the reference point, it is not about us, or about defining Jewish identities, or strengthening Jewish communities.

Parallel to that there was a second development: a resurgence of antisemitism, because hate speech is one of the unavoidable consequences of freedom. If we are fighting for freedom, as we were with the independent underground publishing, we were fighting for everybody's freedom, including that of the scoundrels. But even if underground publishing brought with it some antisemitic publications, the full scale of the phenomenon was visible only after 1989, when censorship was abolished and the underground emerged above ground. My non-Jewish Polish friends had previously been used to saying that they of course understood my sensitivity to antisemitism but that, frankly, I was exaggerating its importance: after all, they had almost never run into it themselves. But when the 'Protocols of the Elders of Zion' became freely available in every other Warsaw church, they realised that, if anything, I had downplayed the extent of the threat. 
Between these two factors of antisemitism and philosemitism - the balance between them perpetually shifts, and right now we are going through a particularly nasty time - there remain the Jews. To be sure, if I had to choose between antisemitism and philosemitism, I would choose the latter - but frankly, I would prefer everybody to leave me in peace. Not much chance of that now, of course, and not much chance then, when we were trying to sort ourselves out while caught in a rather extraordinary set of historical circumstances, between the fall of Communism and the eruption of freedom.

When I say 'we' I mean the generation of Polish Jews born after the war, raised under Communism - and essentially raised Polish. If someone had a strong Jewish identity of any kind, they would by that point already have left. Religious Jews would have moved to places where they would not need to worry about kosher food, their children marrying Jews, and whether there would be a minyan at shul.Zionists too had left; with the exception of the years 1949 to 1956, aliyah had always been possible. To be sure, there was harassment and red tape, but you could travel to Jerusalem directly, not by the way of Siberia, like the Soviet refuseniks. But this also meant that Polish Zionists did not leave behind a heroic legend, as the refuseniks did. As a result, the two main poles of Jewish identity formation - the religious and the Zionist - were simply not there any longer in Poland.

Those who remained came under two main headings. Some simply continued the pre-war tradition of Jewish political left-wing radicalism and still hoped that, as Karl Marx had promised, Communism would solve the Jewish question by doing away with the Jews, moulding them into one supranational progressive humanity. Others continued the prewar tradition of assimilationism, and simply considered themselves Polish, believing, as assimilationism had taught, that you can will yourself into becoming part of another nation by giving up your own. In both groups there were the original believers and the post-war late joiners, but that division was secondary. What mattered was that both groups discovered, in I968 if not sooner, that these promises were false. Then many of them left too.

Those who remained essentially came from families that had moved so far away from any Jewish identity, or any method of 'solving the Jewish question', that they did not even reject their Jewishness, of which they had at best a very dim recollection. Their parents or grandparents had done a good job: their descendants no longer really knew they have another identity they should worry about, let alone embrace. I come from a mixed marriage, and my mother's family was two generations assimilated. I did not even bother denying I was also Jewish. It was that unimportant. Others had learned of their Jewishness as a guilty family secret, to be kept hidden but not endowed with any particular meaning. Hardly anyone had any useful knowledge of anything Jewish. Such were the people who would find themselves endowed with the task of rebuilding Jewish life in Poland after 1989.

In Warsaw, a group of young Poles of Jewish origin and their non-Jewish Polish friends had, in the late I970s, set up something we called the Jewish Flying University. The 'flying university'was a time-honoured Polish institution, referring to groups of people who would meet in private apartments to discuss whatever the government preferred they did not discuss. This tradition, which started before the First World War, was reborn in the late I970s, when groups of people started meeting to study history, literature, the economy - all subjects so heavily censored that their public debate would have been either impossible, or a travesty. The Jewish Flying University met to discuss things Jewish - another forbidden topic. 
To be sure, there were also other, much more Jewish Jews. There was the synagogue, nominally Orthodox and clearly geriatric, with barely a minyan to keep it going - but each member of the minyan carried with him enough memories of horror to populate all our nights with nightmares. There was the officially sanctioned Jewish Socio-Cultural Association, which spoke Yiddish, ate ham, and read Jewish authors in worn-out Yiddish editions. Both were at war with each other, feuds of ancient militant Bundists and devout Hassidim we could not even begin to understand - but both had to report on everything to the Interior Ministry, and denounce other Jews if need be. Not out of any, even twisted, ideological condition, but that was the price for having a Yiddish library or matzot for Pesach. They were survival, not renewal - and the kind of survival we, the Jewish newcomers would consider, in our naïve victorious optimism, unacceptable. The fact that they were much more representative - in term of identity, not of activity - of the existing Jewish population did not bother us then.

For we had the political credibility of having been part of Solidarity, part of the underground, and having, much to everybody's surprise, including ours, emerged as winners. We became the public face of Polish Jewry, yet we knew next to nothing about being Jewish. But there was a shortcut: of the organisers and activists of the Jewish Flying University most had during the I980s either become religious or Zionist. Of the latter, most then made ali$y a h$, and religiosity became the identifying factor of the new, reborn Jewish identity. All this was happening within a small group of several dozen young and middle-aged people, part of a larger community of barely a couple of thousand. In other words, we did not have enough Jews to make up a Jewish street where identities could be produced and thrashed out. We had to use what was on the menu - and religiosity and Zionism were the two readily available options.

Since the few Zionists would eventually leave, religiosity became de facto the only option. Of the many facets of it we unhesitatingly chose Orthodoxy, as the one which had a built-in unchallengeable guarantee of authenticity. We failed to realise, however, that in so choosing we were fulfilling the expectations of a segment of Polish society, which wanted its Jews to be 'proper'Jews: bearded, kosher, acting and speaking accordingly, and therefore clearly proving that they are different from Poles. Not necessarily worse, for some passionately equal, but certainly unable to be Poles the way Poles naturally are. And at the same time we were the incarnation of the fears of a segment of the Jewish population, represented by the SocioCultural Association - for we were exactly the kind of Jew that their parents or grandparents had rebelled against, when different kinds of Jewish identity were still available. On top of all that we had become the public face of Polish Jewry, and belonged among the victors of a huge political transformation, conducted in the name of liberty. That was one big balagan.

We were at that time clueless. We had no idea that the individual spiritual choices we were making had a sociological impact and a historical background. Nor were we aware that we were also problematic for the religious segment of Polish Jewry, the one which in theory we were closest to. When in the early I980s I started going to shul, I realised I was the youngest congregant by two generations. The elderly gentlemen took some time to deign to notice I was there, and then asked me the fundamental question: 'Redst du Yiddish?' 'Nie', I answered in Polish - 'no'. 'Un du bist a Yid?' they responded bewildered, and left it at that. It took me quite some time of patient presence, and clumsy prayer, to have them reconsiderbut when they finally decided that I might be Jewish, after all, they told me to get the hell out 
of here and go to Israel, where they need me in the army. If I couldn't be Jewish the Yiddish way, I should become Jewish the Israeli way, and stop bothering them.

I understood them very well. When you were seventy, and had lived those seventy years throughout the twentieth century as a Jew in Poland, the last thing you wanted was more trouble - and we clearly were trouble. With our obvious Solidarity connections, with our no less obvious and no less troublesome Polish identities, we could not fail to alarm the powers that be, and irritate the Jews as well. After 1989 we learned that the communal authorities had a great deal of explaining to do to their minders from the secret police, about why there were young Jews at shul.

We had not been terribly convincing, on the other hand, to Marek Edelman either. The veteran atheist Bundist, deputy commander of the Warsaw Ghetto uprising, staunch antiCommunist and Polish patriot, who had joined the democratic opposition, took a dim view of our espousal of Jewish identity. We had proudly invited him to one of our early Jewish Flying University meetings, and after it was over, he said: 'You are not Jews, you are literary fiction. The Jews are dead, and you have invented yourselves. Don't waste my time.' We could cooperate, yes - but on the basis of shared opposition activities, not of a presumed common Jewishness to which in his eyes we did not belong. He never actually retracted his words but, some fifteen years later, stopped telling us that we are only literary fiction. Marek was never known for his capacity to admit he might have been wrong, and I take this change as ultimate recognition.

The irony of it all is that we were not only unrepresentative of the Polish Jewish population as it existed at the time of the postCommunist transformation, but we were also supremely unrepresentative of the history of Polish Jewry. We were at best a continuation of the ro to 15 per cent of the pre-war Polish Jewish population who were sufficiently assimilated to consider themselves Polish - not that anybody else did. To the Poles they remained Jews, to the Jews they were traitors. They were numerous enough to create a microcosm of their own civil society, but it would certainly not have occurred to them that they were representative of Polish Jewry - yet we, their children and grandchildren, now were.

We also did not realise that what to us was the logical choice, given the lack of other Jewish identities and models, to other Jews was a threat. Our choice of religiousness was neither opportunistic nor political. We had chosen this path for individual spiritual and moral reasons, we knew why we were there - yet to some other Jews our choice was an implicit, or explicit, criticism of the identity choices they had made. This included some Israelis, who after 1989 had moved, or moved back, to Poland from an Israel in which they felt threatened by the growing presence of religiosity in public life - and they discovered, to their horror, that the enemy was already there. The beards were there!

One of these Israeli émigrés, Shoshi Ronen, a brilliant woman who went on to teach Hebrew at Warsaw University, published a broadsheet attack against us in the early I990s in Gazeta Wyborcza, the largest Polish daily paper I write for. She accused us of actually fooling people, by telling them that being Jewish is about Torah, and kashrut, and mitzvot. No - she argued, it is about Einstein, and Freud, and Kafka, and Singer! Anything but observance. Eventually, a debate was organised between her and myself, at the club of the Jewish Socio-Cultural Association. The club was chock-full - and I never lost a debate that badly. The audience not only rooted for my opponent, but accused me of claiming that if one does not conform to my version of Jewishness - the Torah and kashrut and mitzvot 
one - one is not Jewish. I was stunned. The thought had never occurred to me to allege that other Jews were not Jewish. All I was saying was that religious Jewishness was the only full Jewish identity available to the assimilated Jews of Poland at the turn of the century.

After all, the empirical evidence that one can be non-religious and Jewish was sitting in that club and yelling at my face. But what I had failed to understand was that their way of being Jewish - the Yiddish-and-ham way - was not only non-religiousness, a negative identity. It was - or, more precisely, it had been - a different Jewishness, a positive identity, based on the politically radical belief in a better world of social justice, which would implement the moral teachings of the prophets. It had been a Jewishness in conflict with the identity I had adopted, and had in the meantime become meaningless once the religious Jews had been murdered, and therefore there was nobody to be Jewish against in that particular way. But it was a Jewishness, a Yiddishkeit.

And by saying that only a religious identity can, under our circumstances, be fully Jewish, I was, without knowing, attacking them in their very Jewishness, a Jewishness which once had been a vibrant alternative on the Jewish street, and which they had since remained loyal to, even though it meant paying a hefty price within a Polish, national and religious civil society. Shoshi Ronen's broadsheet spoke to that. My endorsement of religious identity did not. Small wonder I became the object of sustained attack. I was ultimately saved by a sweet old lady, who stood up to say that she had known my mother, of blessed memory, well, and that she was sure I had meant well.

The defeat in the debate notwithstanding, we remained the public face of Polish Jewry, since we were unquestionably part of the new, triumphant and well-meaning public face of the new non-Communist Poland. Since we went to shul, this is where people went as well, and brought their problems with them. And we were supremely unprepared to help them.

This, in retrospect, was a fundamental turning point in the recent history of Polish Jewry. Thousands of people were emerging from the closets, willing, perhaps for the first time, to publicly claim their Jewishness, the very same Jewishness that had been a burden for so long, for which they had paid a price or had feared they would; a Jewishness which often did not, at the same time, meet halachic requirements, and certainly did not express itself through any recognisable Jewish activity. In other words, we were getting new Yidn, but together with their old tsures, the archetypical Yiddish word for trouble. And we did not know what to do with them.

The Socio-Cultural Association, tainted by its long history of compromise with the regime, seemed beyond salvation. The shul had to compromise no less, but at least not in public, and our presence gave it a moral and political credibility the Association did not have. But the shul itself was dysfunctional, economically broke, with no social, let alone therapeutic, services to speak of, and with initially just one rabbi, an elderly gentleman imported from Bnei Brak, to whom we all, from Association Jews, through Solidarity Jews, to out-of-the-closet Jews, looked like Martians. There was really nobody to help the newcomers feel welcome in the shul, let alone address their tsures. So they hung around for a while, and then most of them left. They found their own ways of dealing with their conflicted Jewish legacies, which did not involve the Jewish community.

Those who had the guts to remain helped rebuild and transform the community, and eventually also made it a resource for others. But in the meantime we lost probably thousands of prospective members, whose participation, tsures and all, could have made it possible to rebuild a small Jewish street, a community of diversity and ideas. Eight thousand 
nationwide, our strength today in a nation of 38 million, is not really a community; it is but a survival strategy.

To understand just how dramatic the tsures was, let me just recall the case of a Polish peasant, a middle-aged man, who showed up in shul one day in the mid-r99os. His father had passed away just a few days earlier and, on his death-bed, he had told him: 'Staś, you know that of all our children you are the one we love best. Yet you have to understand that you will not inherit the land. You see - you are not, contrary to what you believe, our blood. You are in fact not one of our children, but a Jewish baby we had saved from the ghetto right after your birth; your parents had given you to us before they were killed. So you understand that, as a Jew, you cannot inherit Polish land. But we love you with all our hearts.'

This man had spent his entire life as a Polish peasant, Catholic, vaguely antisemitic, not very educated. And now his entire world was tumbling down around him. So he came to ask of those who, as he had just learned, were his true people: what is he supposed to do with the rest of his life? 'Should I get circumcised? Should I go to Israel?'Today we have therapy, counselling and support groups; then we had nothing. The best advice we could give him then was that he should return to his village and try to pick up his life where he had left it. I hope it worked; he never showed up again. But I know he deserved better, and we failed.

Part of the problem was, of course, that for all our fine words we were not really sure if Edelman had not been right, after all: were we not just literary fiction? We needed criteria of belonging stronger than just our individual commitments. This is why a vote over conditions of membership in the Warsaw kehillah in the late I99os turned out to be so dramatic. Initially the conditions were strictly halachic, but then a motion was made to replace them with the Israeli Law of Return criteria, to allow people who were Jewish from the wrong parent to join as well. To be sure, halachic criteria would still be applied to being counted in the minyan, but kebillah membership was broader than that.

I thought the idea was fair, and in any case we needed more Jews. I supported the motion, but suggested we might want to go one step further, and allow membership for people who were not of Jewish extraction, but had shown continued commitment to the Jewish people, were of no other religion, and wanted to join. I was thinking of a small and very special group of people, a half-dozen or so of the non-Jewish wives of members of the kehillah, who had set up Jewish homes, encouraged their husbands to lead Jewish lives, raised their children Jewish though halachically they themselves were not, but for some reason or another had not wanted to have a giyur - a conversion. The community owed them, and I thought that membership in the kehillah was a symbolic way of expressing our gratitude, and acknowledging togetherness.

My suggestion was rejected, sharply and uncompromisingly, by younger members of the kehillah, who had joined over the last few years, sometimes after a giyur. They demanded that there be a clear line between us and them, and that what I was suggesting blurred that line. My counter-argument, that from a halachic perspective it makes no difference, if the mother is not Jewish, that the father is Jewish or not, made no impression. They wanted not halacha, but confirmation, that they were in and others were out. Young identities do not tolerate experiments.

Nor was the shuls attractiveness a universal given. For many Poles of Jewish origin, brought up in an Enlightenment climate of secularism and rationalism, becoming religious was a step back to a darker age, and endorsing Judaism was particularly troubling. My mother had, more than everything, been embarrassed by my choices: she had given me a good education, 
and I end up like this? One of her friends had gone one step further and once asked me: 'All right, I understand: religion is supposed to make dying easier. But does it have to be Judaism? If you really have to go religious, why not become a Catholic? Not only because it is politically safe, but objectively. I mean just compare: the Catholics, for instance, have the Psalms - such beautiful spiritual poetry. And us, frankly - what?'

This level of not knowing our own tradition was extreme, but hardly an isolated case. And, frankly, it is not obvious that we ourselves were that much more advanced. We had made our choices earlier, and we had the time to develop them, but in fact we had committed ourselves before really knowing what it is we are committing ourselves to. 'Naaseh ve nishma' ('We shall do and we shall hear', Exodus 24:7) - as the Jewish people had said at Mount Sinai. The fact that we did not even know we were repeating that promise just shows how ignorant we were. It also shows that it works.

The Orthodox shul as the central focus of Jewish identity lasted but briefly. New shuls started popping up: non-Orthodox, Liberal, Reform, an occasional Conservative attempt, and then even more Orthodox, Chabad. We immediately engaged in a Jewish war over who is 'really' Jewish and who can officially claim the title. This diversification, and the wars that followed, proved to be of little concern, however, to most Polish Jews. Since the Jewish institutions, such as they were, had shown themselves not to be terribly helpful in resolving those re-emerging Jews' identity issues, people started solving them on their own, which usually meant reclaiming, with somewhat more conviction, their Polish identities, but this time usually with some sort of Jewish strain attached.

The fact that a substantial chunk of Polish civil society was genuinely welcoming of this kind of diversity helped a lot. In the early I99os the discovery that grandma had been Jewish was a world-shaking event. Today it is mostly a biographical curiosity of no major import - even if it is better if the said grandma was on the father's side, not on the mother's. Then it often entailed a sense of obligation to do something about it, to at least entertain the possibility of trying to own up to this legacy, and become a card-carrying Jew. The difference was due to the fact that, raised in a society in which the nation was the only legitimate source of identity, we felt that if we claim our Jewishness, we are supposed to go all the way with it. Today identity is deemed private, not public; individual, not collective - and hyphens in it are considered entirely legitimate - even if there are still milieux and areas where it is better to keep knowledge of the discovery private. But in any case the Orthodox community is no longer the get-to address if you want to do something Jewish.

Most of the interesting Jewish activities today are not necessarily connected to the community. They are performed by people who are Jewish and something else: Jewish and LGBT, Jewish and politically active, Jewish and this or that - who are Zwischen, in-between different identities. And this 'in-betweenness' is often creative in its own right. A number of very creative people - writers, artists, actors identify as Jewish, but are often not part of the community. We, the eight thousand, are too small a community to be creative - and we are therefore not attractive to creative people who could change that. To be sure, we have lots of creative individuals, but their artistic, cultural or literary performance cannot, because of the numbers, generate reactions strong and diverse enough; their public exists essentially outside the community.

It does not really get much better even if you include the Groucho Marxists. Groucho Marx famously said: 'I am too proud to belong to a club that would have me'. Poland's Jewish 
Groucho Marxists, who publicly identify as Jews but do not affiliate with Jewish organisations, can be roughly estimated at some 15,000. The number of people who still believe it is safer to be Jewish in private only is, of course, unknown and unknowable. So is the number of those who do not even know they are Jewish, and never will, for their parents or grandparents had done too good a job passing as Poles.

Given all that, and given the dramatic history of Polish Jewry, the very existence - and persistence - of our community is something difficult to explain. And frankly, I would not be able to explain it at all if not for something I have discovered, somewhat to my surprise, regarding my own Jewish identity: it is fun to be Jewish. Not rip-roaring fun, not the kind of fun you turn to entertainment for. Rather the quiet pleasure of participating in a very long undertaking to produce sense and values, premised on the fact that we question the sense and values we produce. The intense satisfaction of mastering a knowledge which is completely useless outside its frame of reference - like mathematics is, or music - but which makes that frame of reference supremely useful. An interaction of mind and text, bringing out the best from both. And, yes, an encounter with the divine, if only through its footsteps.

This is why I believe our story, while remaining that of a small and not particularly important community, has general Jewish relevance. For it shows that it makes sense to be Jewish, to do Jewish, to think Jewish even under unsupportive circumstances. In the long run this gamble pays off, as it had for us. And this is relevant not only for Poland at the turn of the century. This is what has kept us going for the last 35 centuries, in Israel and the diaspora. The problem is that there is no way to experience it yourself, personally and not second-hand, unless you are willing to repeat the process yourself - and the beginnings take time and are usually not fun.
It also gets more complicated with time. We started off with an attempt to rediscover and re-endorse Jewish identities while interacting with both anti- and philosemitism. Both factors are there, and the first is a much more immediate concern, but two further elements now need to be considered. One is our relationship with Israel: a gut-level identification and solidarity is accompanied by growing discomfort. One of the elements which turns us off during visits to Israel is the intense visibility of national flags and uniforms. We in the diaspora have learned that these elements do not spell safety to us and, while we understand this is not necessarily true of Israeli uniforms, our concern about the smothering presence of national flags, both literal and metaphoric, remains. They are there to express the kind of bond between blood and soil which we are not part of in the diaspora, and find it difficult to be associated with in Eretz Israel. For many years Israel was the driving force of Jewish identity, but today we are no longer sure if it is, or even if we want it to be. We have learned to be allergic to nationalism, even our own. As my zeyde of blessed memory used to say: 'Do not scare me away with nations - I want to live in society'.

The second issue which needs to be mentioned is 'Holocaust identity'. For obvious reasons I do not normally use the term 'Holocaust', I say 'Shoah', but in this particular context the wording is right. In a nutshell, this refers to the idea that you should be Jewish because, had you been Jewish then, they would have murdered you. What a great reason to be Jewish! It stands behind the Holocaust tours, from Israel and from the diaspora, which we witness in Poland every year. These tours no longer ignore us, as they did for many years earlier: they just consider us irrelevant. In their optics, Poland matters because it is the site of Auschwitz, Treblinka, and the Warsaw 
ghetto - and yes, there are a few Jews still living there. As if there had not been the Remuh and the Bund, Chassidism and Janusz Korczak, Singer living on Krochmalna Street and Jewish anarchists defending Białystok. As if the only thing about Polish Jews that mattered was that the Germans had come and killed them all. No, I am not pleading for the recognition of Polish Jews to make Polish Jews feel good. I am demanding it to prevent other Jews from going stupid.

And yet the current approach, in which our existence is actually at least acknowledged, is an improvement. In the first years of the March of the Living, Polish Jews from Poland were banned from participating, for their very existence spoiled the narrative that Poland is the place of death, which you can only flee or visit, but not live in out of your own free will. This ban was lifted only in 1994, when the organisers gave in to requests from non-Jewish Poles who wanted to participate in the March to express their solidarity with the Jewish people. The Poles were accepted and take part to this very day - but then Polish Jews could no longer be excluded. I am not a great fan of the March, and the exclusion of our young people

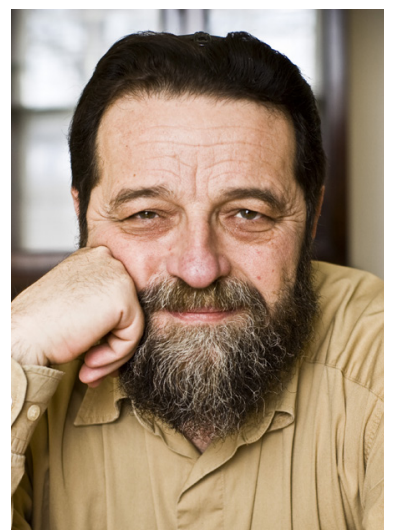

Konstanty Gebert, born 1953, Warsaw. International reporter and columnist with leading Polish daily Gazeta Wyborcza. Democratic opposition activist in the 1970s, free trade union co-founder, 1980, underground journalist (pen name: Dawid Warszawski, which he still uses) in the 1980s. Co-founder i.a. of the underground Jewish Flying University, did not particularly offend me, or them. It is the way of thinking which stands behind it that worries me.

So today we have to carve out our Jewish identities in confrontation not only with two non-Jewish factors, anti- and philosemitism, but also two Jewish ones: Israeli nationalism, and the civil religion of the Holocaust. Antisemitism wants us to stop being, or at least stop being Jews; philosemitism very much wants us to be Jews, but such Jews as fit the philosemites' expectations. Israeli nationalism wants us to accept in Israel that which we do not accept at home, and the civil religion of the Holocaust infuses us with the belief that being Jewish, at least in the diaspora, is about death, not life.

If all this seems complicated, and not self-explicatory, it is because it is. But against all these pressures, being Jewish remains an extraordinary adventure. We have 35 centuries of experience in arguing with text, arguing with other Jews - and, yes, having fun on the way. That worked for us under the rather unpleasant circumstances of late-Communist Poland; if it worked there, it can probably work elsewhere as well.

Polish Council of Christians and Jews, and of the Polish Jewish monthly Midrasz. Author of eleven books, i.a. on Poland's round table negotiations of 1989, the Yugoslav wars, Israeli history, Torah commentary. Board member, Paideia; advisory board member, Einstein Forum, Dutch Jewish Humanitarian Fund; preparatory board member, European Press Prize; associate fellow, European Council on Foreign Relations. Visiting professor i.a. Hebrew University, UC Berkeley, Grinnell College. Latest publication: 'From Round Tables to Divided Societies: Poland and Central Europe Thirty Years after the Fall of Communism', in The Israeli Journal of Foreign Affairs, 13 (2019). He is currently working on a book on comparative genocide. 